\title{
SEXTING AND REVENGE PORNOGRAPHY. LEGISLATIVE AND SOCIAL DIMENSIONS OF A MODERN DIGITAL PHENOMENON. PHIPPEN, A.; BRENNAN, M.
}

by

MICHAELA DVOŘÁKOVÁ*

Phippen, A.; Brennan, M. (2020) Sexting and Revenge Pornography. Legislative and Social Dimensions of a Modern Digital Phenomenon. Abingdon, New York: Routledge, $164 p$.

In Sexting and Revenge Pornography, Andy Phippen and Maggie Brennan present an empirical and legislative analysis of non-consensual sharing of intimate images ${ }^{1}$ among adults and minors and discuss associated aspects, including social dimensions. While drawing almost exclusively from data and legislation in the United Kingdom, their critique and well-argued suggestions appear universal with the potential to become implemented across different legal systems.

Sexting is usually defined as any form of electronic communication between two people (regardless of age), containing sharing of their nude pictures. It does not cause any harm by itself. Revenge pornography, on the other hand, is highly harmful. It consists of such intimate pictures being further shared (without consent), posted online, or used in for extortion. ${ }^{2}$ Nevertheless, these terms have a slightly different meaning in Phippen and Brennan's view. In their perspective, the decisive criterion is

407928@mail.muni.cz, Ph.D. student at the Department of Constitutional Law and Political Science, Faculty of Law, Masaryk University, Czech Republic.

See the abstract (p. $i$ ) of the book.

2 Powell, A. and Henry, N. (2017) Sexual Violence in a Digital Age. [online] Basingstoke: Palgrave Macmillan, pp. 119-120, 132-133, 162-164, 240-241. Available from: https://doi.org/10.1057/978-1-137-58047-4 [Accessed 30 March 2021]. 
the victim's age. If minors self-generate and share their intimate pictures or further share such images of others, it is "sexting", whilst it is "revenge pornography" if adults (over 18 years old) do it. ${ }^{3}$ This is an unusual approach. However, such distinction of the terms derives from UK legislation. As explained below, the non-consensual pornography regulations are very different for minors and for adult victims. Paradoxically, in the case of minors, the regulations may be even less effective.

Either way, sexting and revenge pornography fall under the concept of "image-based abuse", as the authors explain. ${ }^{4}$ Although other scholars usually prefer "image-based sexual abuse", 5, 6 both terms have the same meaning - Phippen and Brennan repeatedly point out the need to acknowledge the underlying sexual nature of sexting and revenge porn themselves. However, it would bring more clarity to use the already established terminology (which also includes the term "non-consensual pornography"7). In that regard, the authors express their belief (shared by some other scholars ${ }^{8,9}$ ) that the term "revenge pornography" is highly problematic. ${ }^{10}$ Surprisingly, they decided to use it throughout the book and in its title nonetheless.

The book consists of three equally long parts, further divided into two distinct chapters each. The first part analyzes sexting and revenge porn as social phenomena, the second part describes current legislation and its limitations, and the third part focuses on non-legal ways to tackle non-consensual pornography. Unlike other scholars in the field of image-based abuse, Phippen and Brennan have expertise in IT/digital rights and psychology, respectively. Andy Phippen also conducted or participated in empirical research on minors' attitudes toward sexting in $2012^{11}$ and

\footnotetext{
See pp. 33-35 of the book.

4 See pp. 2-15 of the book.

5 McGlynn, C. and Rackley, E. (2017) Image-Based Sexual Abuse. Oxford Journal of Legal Studies, 37 (3), pp. 535-544. Available from: https://doi.org/10.1093/ojls/gqw033 [Accessed 30 March 2021].

6 Powell, Henry, Sexual Violence in a Digital Age, pp. 117-153.

7 Citron, D. K. and Franks, M. A. (2014) Criminalizing Revenge Porn. Wake Forest Law Review, 49 , p. 346. Available from: http://repository.law.miami.edu/cgi/viewcontent.cgi? article $=1059 \&$ context=fac_articles [Accessed 4 April 2021].

8 McGlynn, Rackley, Image-Based Sexual Abuse, p. 536.

9 Powell, Henry, Sexual Violence in a Digital Age, p. 118.

10 See p. 42, 52 of the book.
} 
$2017,{ }^{12}$ and key findings from this research are reported in the reviewed book. They serve as the basis for his and Brennan's critique on the policy-making process regarding youth sexting. The data obtained from these surveys present a highly needed evaluation of teen sexting. It is evident that children's attitudes toward it have not changed significantly over the years, and neither have the policymakers'.

Apart from these findings, the first part of the book lacks substantial novelty and provides only a few new ideas. Compared with other publications from the field, like that by Henry et al. ${ }^{13}$ (also published in 2020), Sexting and Revenge Pornography appears rather superficial. Therefore, it would have been preferable if the authors had not attempted to cover all aspects of non-consensual pornography that are already well examined by other scholars. ${ }^{14}$ For instance, they mention pornographic deepfakes (calling it, inconveniently, "pseudo-sexual imagery") but do not elaborate on it much further. ${ }^{15}$ Phippen and Brennan are indisputable experts on teen sexting, and it is clear from the book that image-based abuse of minors is their main research agenda. Because of that, it might have been suitable if they devoted more space to it and went deeper into their findings at the expense of adult revenge pornography.

11 Phippen, A. (2012) Sexting: An Exploration of Practices, Attitudes and Influences. NSPCC. Available from: https://www.nspcc.org.uk/globalassets/documents/researchreports/sexting-exploration-practices-attitudes-influences-report-2012.pdf [Accessed 5 April 2021].

12 UK Safer Internet Centre, University of Plymouth, Netsafe and Office of the eSafety Commissioner. (2017) Young People and Sexting - Attitudes and Behaviours. Research Findings from the United Kingdom, New Zealand and Australia. Available from: https://www.netsafe.org.nz/wp-

content/uploads/2017/12/Young_people_and_sexting_Attitudes_and_behaviours.pdf [Accessed 5 April 2021].

13 Henry, N. et al. (2020) Image-based Sexual Abuse. A Study on the Causes and Consequences of Non-consensual Nude or Sexual Imagery. [online] London: Routledge, 200 p. Available from: https://www.taylorfrancis.com/books/mono/10.4324/9781351135153/image-based-sexualabuse-nicola-henry-clare-mcglynn-asher-flynn-kelly-johnson-anastasia-powell-adrian-scott [Accessed 5 April 2021].

14 For example, see: McGlynn, Rackley, Image-Based Sexual Abuse, pp. 534-561. Powell, Henry, Sexual Violence in a Digital Age, 317 p. Citron, D. K. (2019) Sexual Privacy. The Yale Law Journal, 128 (7), $\quad$ pp. 1924-1928. $\quad$ Available https://www.yalelawjournal.org/article/sexual-privacy [Accessed 5 April 2021].

15 The area of pornographic deepfakes deserves more attention, as their use is rapidly growing. For more information, see the following: Hao, K. and Heaven, W. D. (2020) The year deepfakes went mainstream. MIT Technology Review, 24 December. Available from: https:/www.technologyreview.com/2020/12/24/1015380/best-ai-deepfakes-of-2020/

[Accessed 10 April 2021]. Delfino, R. (2019) The Case for Federal Criminalization of Revenge Porn's Next Tragic Act. Fordham Law Review, 88 (3), pp. 887-938. Available from: https://ir.lawnet.fordham.edu/flr/vol88/iss3/2/ [Accessed 8 April 2021]. 
In contrast, it is enormously meritorious that the authors present a sensitive approach towards victims of image-based sexual abuse. They rightly refuse the common belief that if someone self-generates and shares their intimate pictures, they are at fault for any further misuse and associated harm. Phippen and Brennan see this so-called "victim blaming"16 as destructive and irrelevant because only abusers should be held accountable for causing abuse, not victims. Concerning children and teen sexting, their effort to be understanding is even more apparent. That is especially sympathetic because many young participators in the 2012 and 2017 surveys expressed their wish not to be judged by adults for sharing intimate pictures. ${ }^{17}$

The authors also emphasize that minors will participate in sexting, no matter how much effort is there to prevent it. This conclusion may be one of the greatest contributions of the book. For children, sexting has become a big part of their lives and a standard form of communication. Sadly, they also see it as a way of establishing romantic relationships or increasing their self-confidence. Hence, peer pressure to participate in sexting is intense. For that reason, Phippen and Brennan make a very clear point we should not focus on sexting as the act itself, but on the motives, forces, and reasons behind it. ${ }^{18}$ I could not agree more. Coercion and manipulation are very common in the context of image-based abuse and many victims are forced into creating the content in the first place. Unfortunately, children are particularly vulnerable to manipulation and often cannot recognize it. Therefore, they should not be blamed for taking part in sexting (especially if they tend to copy adult behaviour). Rather, it is the fault of adults who have failed to educate them about the potential harm of this phenomenon, as the authors explain.

In the second part of the book, Phippen and Brennan analyze the legal aspects of sexting and revenge pornography. Although disturbing and surprising, one of the main conclusions is that the law protects adult victims of image-based abuse better than minors. ${ }^{19}$ The principal reason behind this very absurd outcome of the law is that if children self-generate and/or share

\footnotetext{
16 Starr, T. S. and Lavis, T. (2018) Perceptions of Revenge Pornography and Victim Blame. International Journal of Cyber Criminology, 12 (2), pp. 428-429. Available from: https://www.cybercrimejournal.com/Starr\&Lewisvol12issue2IJCC2018.pdf [Accessed 11 April 2021].

17 See p. 17,138 of the book.

18 See pp. 123-124 of the book.
} 
their intimate pictures, they may face prosecution for creating and distributing child pornography. ${ }^{20}$ Children are also often reminded of such possible consequences of sexting, sometimes even by police officers. According to the authors, this attitude does little to protect children from sharing their intimate images but does a lot to discourage them from reporting consequent abuse to the police. Moreover, it does not differ whether a child shares the intimate images voluntarily or not. Although some other countries ${ }^{21}$ also enable prosecution of children who take and share their nude pictures, it seems the situation is by far the worst in the UK. For this reason, the findings on harm caused by such legislative approach presented in Sexting and Revenge Pornography can very usefully serve as a "bad practices" example that is not to be followed.

As mentioned above, the third part of the book moves more into what the policymakers and other stakeholders are doing wrong in tackling non-consensual pornography. ${ }^{22}$ On this count, the authors present their well-reasoned conclusions based on three different findings. Firstly, they emphasize the lack of effectiveness of any prohibitive approaches. ${ }^{23}$ It is important to realize that children share their intimate pictures regardless of illegality of such action, and the law should not punish them if it does not cause any harm. However, at the same time, it should protect them in the event of further abuse based on the initial sharing. ${ }^{24}$

Secondly, there should be proper education available to children on the risks of electronic communication, the concept of consent in romantic and sexual relationships, the many forms of manipulation or coercion, and

19 The different levels of protection for adults and minors regarding non-consensual pornography are partly caused by the fact that the UK has criminalized revenge porn. In contrast, in countries that have not implemented such law, it would not be the case.

20 See pp. $18,68-70$ of the book.

${ }^{21}$ For instance, in the US, Canada, France and the Czech Republic. See the following: O'Connor, K. et al. (2017) Sexting Legislation in the United States and Abroad: A Call for Uniformity. International Journal of Cyber Criminology, 11 (2), pp. 218-245. Available from: http://cybercrimejournal.com/O\%27Connoretalvol11issue2IJCC2017.pdf [Accessed 10 April 2021]. Lee, J. R. and Darcy, K. M. (2021) Sexting: What's Law Got to Do with It? Archives of Sexual Behavior, 50, p. 564, 567. Available from: https://doi.org/10.1007/s10508-020-01727-6 [Accessed 10 April 2021]. Robitaille-Froidure, A. (2014) Sexting : les adolescents victimes (consentantes ?) de la révolution numérique. La Revue des droits de l'homme, 5 (4), pp. 7-9. Available from: https://doi.org/10.4000/revdh.786 [Accessed 10 April 2021]. Patočková, T. (2021) Porno z pomsty. Zmapovali jsme podsvětí internetu, kde se sdílí nahé snímky obětí. Aktuálně.cz, 19 March. Available from: https://zpravy.aktualne.cz/domaci/porno-z-pomstyzmapovali-jsme-podsveti-internetu-kde-se-sdil/r b95bc994810f11ebb2f60cc47ab5f122/ [Accessed 10 April 2021].

22 See p. 140 of the book.

23 See p. 120-127, 135-136 of the book.

24 See pp. 138-141 of the book. 
the right to say "no". ${ }^{25}$ Children should also learn about the harmful impacts of victim blaming. Most importantly, the education on non-consensual pornography should provide them with information on what to do if someone becomes a victim of image-based abuse and what legal remedies are available. It definitely should not lead to terrifying those who have already had their intimate images further shared or who have been threatened with it. ${ }^{26}$

Thirdly, and it is an important note, Phippen and Brennan believe the right path to tackle non-consensual pornography is not treating this issue as a specific modern phenomenon only enabled by technologies. While the possibility to take and share a picture with a click of a button certainly is partly to be blamed for the spread of image-based sexual abuse, the authors emphasize that the underlying aspects are not new at all - it all comes down to consent and its contextual nature. Because of this origin, non-consensual pornography cannot be solved with more advanced technology solutions only (such as new algorithms or "hashing" once reported images). ${ }^{27}$ Despite the inadequacy of "technology-oriented solutions", Phippen and Brennan underline that the onus of tackling image-based abuse currently lies almost entirely upon service providers. ${ }^{28}$ Although it may seem the authors downplay the importance of what service providers can do to fight non-consensual pornography, it is not their intention. They believe service providers to be vital stakeholders who can make a huge difference (which we all could see in December 2020 when Pornhub deleted most of its videos ${ }^{29}$ ). Nevertheless, pressuring service providers to "do more" for its own sake does not solve the problem. Phippen and Brennan's view is that non-consensual pornography must be addressed in complex way, and any such effort must come from a profound understanding of all issues in question. ${ }^{30}$ Prohibition, excessive censorship or pressure on advancing technology are not effective.

\footnotetext{
See pp. 117-127, 130-139 of the book.

See pp. 130, 132-135 of the book.

See pp. 30, 61, 102-110, 141 of the book.

See p. 100 of the book.

29 Valinsky, J. (2020) Pornhub removes a majority of its videos after investigation reveals child abuse. CNN Business, December 15. Available from: https://edition.cnn.com/2020/12/15/business/pornhub-videos-removed/index.html [Accessed 12 April 2021].

30 See pp. 100-102 of the book.
} 
Sexting and Revenge Pornography is worth praise for multiple reasons. In my view, the greatest asset of the book is the urgent and evidence-based call to change the teen sexting-related legislation. The authors contend that children who take nude pictures of themselves and share them with someone else (e.g. boyfriend/girlfriend) should not be prosecuted. On the contrary, adults should try to understand the reasons for such behaviour, explain related risks to children, and offer them help and legal advice if they get subsequently abused. The empirical data presented in the book, altogether with the description of real-life effects of non-consensual pornography on its victims and analysis of the law with its shortcomings, constitute a solid argument to change the current situation. Policymakers and other stakeholders both in the UK and other countries ought to adopt it.

However, I am unsure what is the book's scholarly or practical value in other aspects precisely. Its concept is rather broad and complex, although not deep and thorough in terms of revenge pornography. What could have been the book's greatest strength - its practical use - falls a little short of expectations. Many victims of non-consensual pornography who seek out this book would presumably find it helpful if there were any instructions on what to do in their situation. However, Phippen and Brennan do not offer these.

In contrast, the authors present many suggestions for the regulation of sexting and revenge porn. These are very well-argued and beneficial, but some of them could be rather difficult to implement into law. For instance, Phippen and Brennan say the substance of the revenge porn crime should not lie with the offender's intent but should be based on the victim's harm instead. ${ }^{31}$ As reasonable as such demand may seem, it is also quite problematic. The decisive criteria must be objective, not dependable on subjective and relative consequences. On the other hand, the authors also emphasize the importance of considering the cultural specifics of intimacy and shame concerning the harm of image-based abuse. ${ }^{32}$ That is a good point, indeed.

In conclusion, Sexting and Revenge Pornography is neither exactly practical nor exclusively theoretical but lingers somewhere in between. Phippen and Brennan have undeniably presented an original contribution that is

31 See pp. 20-22, 42-44 of the book.

32 See pp. 43-44 of the book. 
comprehensible and based on empirical evidence. It offers a wide-ranging perspective on what we are now doing wrong in non-consensual pornography (especially teen sexting) and what are the possible actions. The main conclusion is that the legislation and technology-oriented solutions struggle to provide victims with adequate protection, while education and societal changes may be much more effective. Ultimately, this universal conclusion could inspire stakeholders in the UK and other countries as well.

\section{LIST OF REFERENCES}

[1] Citron, D. K. (2019) Sexual Privacy. The Yale Law Journal, 128 (7), pp. 1792-2121. [online] Available from: https://www.yalelawjournal.org/article/sexual-privacy [Accessed 5 April 2021].

[2] Citron, D. K. and Franks, M. A. (2014) Criminalizing Revenge Porn. Wake Forest Law Review, 49, pp. 345-391. [online] Available from: http://repository.law.miami.edu/cgi/viewcontent.cgi?article=1059\&context=fac_articles [Accessed 4 April 2021].

[3] Delfino, R. (2019) The Case for Federal Criminalization of Revenge Porn's Next Tragic Act. Fordham Law Review, 88 (3), pp.887-938. [online] Available from: https://ir.lawnet.fordham.edu/flr/vol88/iss3/2/ [Accessed 8 April 2021].

[4] Hao, K. and Heaven, W. D. (2020) The year deepfakes went mainstream. MIT Technology Review, 24 December. [online] Available from: https://www.technologyreview.com/2020/12/24/1015380/best-ai-deepfakes-of-2020/ [Accessed 10 April 2021].

[5] Henry, N. et al. (2020) Image-based Sexual Abuse. A Study on the Causes and Consequences of Non-consensual Nude or Sexual Imagery. London: Routledge, 200 p. [online] Available from: https://www.taylorfrancis.com/books/mono/10.4324/9781351135153/image-basedsexual-abuse-nicola-henry-clare-mcglynn-asher-flynn-kelly-johnson-anastasia-powelladrian-scott [Accessed 5 April 2021].

[6] Lee, J. R. and Darcy, K. M. (2021) Sexting: What's Law Got to Do with It? Archives of Sexual Behavior, 50, pp.563 - 573. [online] Available from: https://doi.org/10.1007/s10508-020-01727-6 [Accessed 10 April 2021].

[7] McGlynn, C. and Rackley, E. (2017) Image-Based Sexual Abuse. Oxford Journal of Legal Studies, 37 (3), pp. 534-561. [online] Available from: https://doi.org/10.1093/ojls/gqw033 [Accessed 30 March 2021]. 
[8] O'Connor, K. et al. (2017) Sexting Legislation in the United States and Abroad: A Call for Uniformity. International Journal of Cyber Criminology, 11 (2), pp. 218-245. [online] Available from: http://cybercrimejournal.com/O\%27Connoretalvol11issue2IJCC2017.pdf [Accessed 10 April 2021].

[9] Patočková, T. (2021) Porno z pomsty. Zmapovali jsme podsvětí internetu, kde se sdílí nahé snímky obětí. Aktuálně.cz, 19 March. [online] Available from: https://zpravy.aktualne.cz/domaci/porno-z-pomsty-zmapovali-jsme-podsveti-internetukde-se-sdil/r b95bc994810f11ebb2f60cc47ab5f122/ [Accessed 10 April 2021].

[10] Phippen, A. (2012) Sexting: An Exploration of Practices, Attitudes and Influences. NSPCC. Available from: https://www.nspcc.org.uk/globalassets/documents/researchreports/sexting-exploration-practices-attitudes-influences-report-2012.pdf [Accessed 5 April 2021].

[11] Phippen, A.; Brennan, M. (2020) Sexting and Revenge Pornography. Legislative and Social Dimensions of a Modern Digital Phenomenon. Abingdon, New York: Routledge, 164 p.

[12] Powell, A. and Henry, N. (2017) Sexual Violence in a Digital Age. Basingstoke: Palgrave Macmillan, 317 p. [online] Available from: https://doi.org/10.1057/978-1-137-58047-4 [Accessed 30 March 2021].

[13] Robitaille-Froidure, A. (2014) Sexting : les adolescents victimes (consentantes ?) de la révolution numérique. La Revue des droits de l'homme, 5 (4), pp. 1-21. [online] Available from: https://doi.org/10.4000/revdh.786 [Accessed 10 April 2021].

[14] Starr, T. S. and Lavis, T. (2018) Perceptions of Revenge Pornography and Victim Blame. International Journal of Cyber Criminology, 12 (2), pp. 427-438. [online] Available from: https://www.cybercrimejournal.com/Starr\&Lewisvol12issue2IJCC2018.pdf [Accessed 11 April 2021].

[15] UK Safer Internet Centre, University of Plymouth, Netsafe and Office of the eSafety Commissioner. (2017) Young People and Sexting - Attitudes and Behaviours. Research Findings from the United Kingdom, New Zealand and Australia. [online] Available from: https://www.netsafe.org.nz/wp-content/uploads/2017/12/Young_people_and_sexting_ Attitudes_and_behaviours.pdf [Accessed 5 April 2021].

[16] Valinsky, J. (2020) Pornhub removes a majority of its videos after investigation reveals child abuse. CNN Business, December 15. [online] Available from: https://edition.cnn.com/2020/12/15/business/pornhub-videos-removed/index.html [Accessed 12 April 2021]. 